\title{
IDENTIFICATION OF JUNIOR HIGH SCHOOL STUDENTS' ERROR TYPES IN UNDERSTANDING CONCEPT ABOUT RELATION AND FUNCTION
}

\author{
Aflich Yusnita Fitrianna ${ }^{* 1,2}$, Rizky Rosjanuardi ${ }^{1}$ \\ ${ }^{1}$ Universitas Pendidikan Indonesia, Indonesia \\ ${ }^{2}$ Institut Keguruan dan Ilmu Pendidikan Siliwangi, Indonesia
}

\begin{tabular}{l}
\hline \hline Article Info \\
\hline Article history: \\
Received Jan 8, 2021 \\
Revised Jan 20, 2021 \\
Accepted Jan 21, 2021 \\
\hline
\end{tabular}

\section{Keywords:}

Junior high school student, Relations and Functions, Student Conception, Type of Error

\begin{abstract}
This study aims to identify types of errors made by students and their conceptions related to the concept of relations and functions. This research is a descriptive study with a qualitative approach conducted in eight grades at one of Madrasah Tsanawiyah in Kabupaten Bandung Barat. The research subjects were taken from 26 students who answered incorrectly on a given test. The research instrument was in the form of a diagnostic test based on basic competencies and indicators in the Relations and Function material. In-depth interviews were conducted with students who made mistakes in answering. Based on the data analysis, the mistakes made were: 1) conceptual error type $1,2)$ conceptual error type 2,3 ) procedural error, 4) technical error, and 5) error in understanding the problem. One of the causes of students' mistakes is the dissimilar concept between students' and scientific conceptions.
\end{abstract}

Copyright $(2021$ IKIP Siliwangi. All rights reserved.

\section{Corresponding Author:}

Aflich Yusnita Fitrianna,

Department of Mathematics Education,

Universitas Pendidikan Indonesia,

Jl. Dr. Setiabudhi No. 229, Bandung, West Java 40154, Indonesia.

Email: aflichyf@upi.edu

\section{How to Cite:}

Fitrianna, A. Y., \& Rosjanuardi, R. (2021). Identification of junior high school students' error types in understanding concept about relation and function. Infinity, 10(2), 175-190.

\section{INTRODUCTION}

Indonesian 2013 curriculum says that Relation and Functions is a compulsory topic for Junior High School students. In the attachment of Education and Culture Ministry Regulation No. 24 of 2016 states that the basic competencies that must be achieved in the material of Relations and Functions in the aspect of knowledge are to describe and to state relations and functions using various representations (words, tables, graphs, diagrams, and equations), and in the aspects of skills, the material covers solving problems related to relations and functions by using various representations (MECRI, 2016b). Relations are defined as relationships, and a function is defined as a process that connects each element from one set (domain) to exactly one element from another set (codomain) (As'ari et al., 2017; Blanco et al., 2014). Functions are not simple concepts, at least three systems of representation are used to represent the concept of functions in high school. They are tables (including ordered pairs), graphs, and formulas or equations. The characteristics of the 
concept of function make it able to be studied from two perspectives, as a part of mathematics and as an object in learning mathematics (Blanco et al., 2014).

Based on studies regarding the analysis of students' abilities in relation and function material, the following results are obtained: 1) students experience epistemological obstacles related to the concept of relations and functions, 2) students experience misconceptions, 3) students have great difficulty in stating the definition of functions, solving problems in different contexts, and solving problems related to function (Irawati et al., 2014; Istiqomah, 2015). The results of interviews conducted by researchers with mathematics teachers at one of the Tsanawiyah Madrasah in Kabupaten Bandung Barat, showed that the results of students' daily tests on relation and function material obtained an average value of 70.2, which is below the specified minimum completeness criteria, 72. Hence, in this study, the types of errors made by students and students' conceptions of relations and functions will be identified.

Education and Culture Ministry Regulation No. 21 of 2016 concerning content standards in Primary and Secondary Education, states that one of the objectives of mathematics is to understand mathematical concepts, explain the relationship between concepts, and apply concepts or algorithms in a flexible, accurate, efficient, and precise manner in problem solving (MECRI, 2016a). Concepts are ideas that can be used or allow someone to classify an object (Bell, 1981). Abstract concepts are understood as two different forms, structurally as an object and operationally as a process. One is said to have an object of the concept if he/she is able to show the properties of the concept, while someone is said to have had a conceptual process if that he/she can discuss the concept using a mathematical object (Sfard, 1991). A concept can be learned through definition (Simon, 2017). When a student understands the definition of a concept presented in textbooks and classroom learning, the student will form an image of the concept in his mind (Viholainen, 2008). Concept images consist of all cognitive structures in an individual's mind that are associated with a particular concept, while concept definitions are the words used for a concept. Initially a person has a mental picture of a given concept, all visual representations such as graphics, symbols of the concept, as well as a collection of properties related to the concept. The combination of these characteristics with mental images is called concept image (Tall \& Vinner, 1981). Furthermore, the concept image can be used as a guide which has been estimated to be the starting point for the emergence of students' learning difficulties in certain materials and students' conceptions related to a concept.

Zetterberg (1966) provides an explaination that there are three components that make up a concept, they are symbols, objects and conceptions. Conception is a model of explaining learners about a certain concept (Simon, 2017). Another explanation of conception is a form of internal representation of the concept, which is owned by students and becomes an element of a student's knowledge (Sfard, 1991). Bell (1993) states that several reasons for the importance of identifying students' conceptions are: 1) students' conceptions are often not in accordance with scientific conceptions or the conceptions of experts, 2) students' conceptions can help or hinder understanding of other concepts causing students' difficulties in learning. Students' difficulties in solving math problems can be seen from the mistakes made by students. This error can be seen from the identification of the student's work in doing the test (Kariadinata et al., 2019).

Johari and Shahrill (2020) show that it is very important to know the causes of common mistakes made by students. Therefore, the teacher is able to facilitate students in reducing their errors in terms of analyzing the problem and reasoning about every step taken to solve it. Analysis of students 'difficulties in this study was to reveal in depth the types of errors occurred, the factors that caused these errors, and students' conceptions regarding the material of Relations and Functions. 
The objectives of this study are to: 1) identify the types of errors made by students in Relation and Function material, and 2) identify students' conceptions regarding the concepts of relations and functions.

\section{METHOD}

This research is a descriptive study with a qualitative approach. This research involved 26 eighth grade students at one of the Tsanawiyah Madrasah, in Kabupaten Bandung Barat. The research instrument used is in the form of a 6-question-diagnostic test of the Relations and Functions material (see Table 1). Before being given the test instrument, students had received online learning through the whatsapp group by the mathematics teacher, but in this study it would be limited to analyzing student errors seen from the results of student work and interviews. Eight students were selected as interview subjects based on consideration of the types of errors made and the need to confirm students' answers. The interview questions are open-ended, and the questions are arranged based on basic competencies and indicators in the Relationship and Function material.

Table 1. Distribution of indicators and question numbers

\begin{tabular}{|c|c|c|}
\hline Basic Competences & Indicators & Number \\
\hline \multirow{13}{*}{$\begin{array}{l}\text { 3.3. Describing and expressing } \\
\text { relations and functions using } \\
\text { various representations (words, } \\
\text { tables, graphs, diagrams, and } \\
\text { equations) }\end{array}$} & \multirow{3}{*}{$\begin{array}{l}\text { Presenting relations with arrows, } \\
\text { cartesian diagrams, and ordered pairs }\end{array}$} & $1 \mathrm{a}$ \\
\hline & & $1 b$ \\
\hline & & $1 \mathrm{c}$ \\
\hline & \multirow{4}{*}{$\begin{array}{l}\text { Showing examples of functions and } \\
\text { not functions }\end{array}$} & $2 \mathrm{a}$ \\
\hline & & $2 b$ \\
\hline & & $2 \mathrm{c}$ \\
\hline & & $2 d$ \\
\hline & \multirow{3}{*}{$\begin{array}{l}\text { Specifying the domain, codomain and } \\
\text { result area of the function }\end{array}$} & $3 a$ \\
\hline & & $3 b$ \\
\hline & & $3 c$ \\
\hline & \multirow{3}{*}{$\begin{array}{l}\text { Expressing a function in an equation } \\
\text { formula }\end{array}$} & $6 a$ \\
\hline & & $6 b$ \\
\hline & & $6 c$ \\
\hline \multirow{2}{*}{$\begin{array}{l}\text { 4.3. Solving problems related to } \\
\text { relations and functions by using } \\
\text { various representations }\end{array}$} & $\begin{array}{l}\text { Solving problems related to relations } \\
\text { and functions }\end{array}$ & 4 \\
\hline & $\begin{array}{l}\text { Solve problems related to relations and } \\
\text { functions in the form of equation } \\
\text { formulas }\end{array}$ & 5 \\
\hline
\end{tabular}

The data that has been collected, then analyzed of students' answer who made mistakes based on the types of errors and indicators as follows. The types of errors and indicators made by students are as follows (Kiat, 2005): 1) errors in understanding questions (M) are the errors that occur in translating questions are indicated by errors in interpreting the language of the questions, 2) conceptual error type 1 (K1) is an error that occurs because students do not understand the concepts involved in the problem, 3) conceptual error type 2 (K2) is an error arising from the inability of students to determine the relationships involved in the problem, 4) procedural errors $(\mathrm{P})$ are errors due to students' inability to manipulate or 
algorithms even though students already understand the concept behind the problem, 5) technical errors $(\mathrm{T})$ are the errors due to carelessness.

\section{RESULTS AND DISCUSSION}

After checking the students' answers, the results obtained in the form of recapitulation of students' answers to each question (see Table 2). The recapitulation of student's answer is used to see the percentage of students who answered correctly, wrongly or not.

Table 2. Recapitulation of student's answer

\begin{tabular}{cccc}
\hline NUMBER & TRUE & FALSE & NO ANSWER \\
\hline $1 \mathrm{a}$ & $54 \%$ & $23 \%$ & $23 \%$ \\
$1 \mathrm{~b}$ & $4 \%$ & $62 \%$ & $35 \%$ \\
$1 \mathrm{c}$ & $15 \%$ & $42 \%$ & $42 \%$ \\
$2 \mathrm{a}$ & $46 \%$ & $46 \%$ & $8 \%$ \\
$2 \mathrm{~b}$ & $8 \%$ & $85 \%$ & $8 \%$ \\
$2 \mathrm{c}$ & $58 \%$ & $35 \%$ & $8 \%$ \\
$2 \mathrm{~d}$ & $27 \%$ & $35 \%$ & $38 \%$ \\
$3 \mathrm{a}$ & $50 \%$ & $31 \%$ & $19 \%$ \\
$3 \mathrm{~b}$ & $31 \%$ & $50 \%$ & $19 \%$ \\
$3 \mathrm{c}$ & $19 \%$ & $62 \%$ & $19 \%$ \\
4 & $77 \%$ & $15 \%$ & $8 \%$ \\
5 & $8 \%$ & $92 \%$ & $0 \%$ \\
$6 \mathrm{a}$ & $23 \%$ & $46 \%$ & $31 \%$ \\
$6 \mathrm{~b}$ & $38 \%$ & $31 \%$ & $31 \%$ \\
$6 \mathrm{c}$ & $15 \%$ & $42 \%$ & $42 \%$ \\
\hline
\end{tabular}

Based on Table 2, the students made mistakes in almost all the question numbers. The types of errors made by students were classified according to the types of errors that were made. 


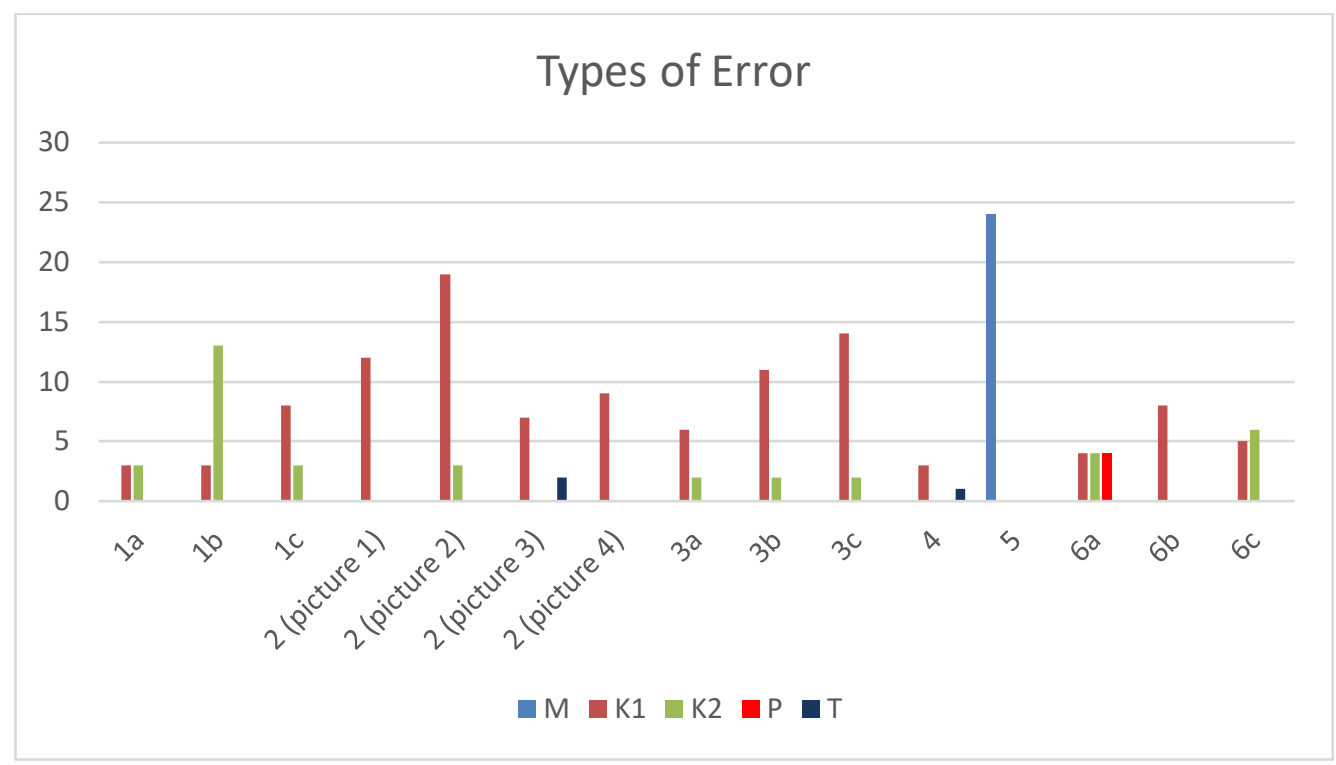

Figure 1. Students' types of errors recapitulation

The types of errors made by students shown in Figure 1 are quite diverse. To see the percentage of students who made each type of error (see Table 3 ). Table 3 is used to compare the number of students who make one type of error with another through the percentage.

Table 3. Percentage of students' error types

\begin{tabular}{cccccc}
\hline \multirow{2}{*}{ Error Types } & \multirow{2}{*}{ Understanding Question } & \multicolumn{2}{c}{ Conceptual } & \multirow{2}{*}{ Procedural } & \multirow{2}{*}{ Technical } \\
\cline { 2 - 5 } & & Type 1 & Type 2 & & \\
\hline Percentage & $13 \%$ & $62 \%$ & $21 \%$ & $2 \%$ & $2 \%$ \\
\hline
\end{tabular}

Based on Table 3, it can be seen that type one conceptual error (K1) and type two conceptual error (K2) were mostly committed by students. This is in accordance with research of Hidayat and Sariningsih (2018) that the mistakes often made by students in solving math problems, one of which is a conceptual error. The eight subjects selected for analysis on the results of their work, not all of them commit these types of errors. Each question related to the causes of errors made by students and students' conceptions related to indicators on the questions will be analyzed.

\subsection{Error Analysis on Question Number 1}

The first indicator for question number one is to present a relation with an arrow diagram, a cartesian diagram, and a set of consecutive pairs. The question can be seen in Figure 2.

The results of Ayu, Beni, Citra and Dodi mathematics tests are $80,70,60$, and 90 respectively. If $A=\{B e n i, C i t r a, D o d i\}$ and $B=\{30,40,50,60,70,80,90,100\}$, state the relation from the set A to B by: a) Arrow diagram, b) Consecutive set of pairs, and c) Cartesian diagram.

Figure 2. Question number 1 for the first indicator 
Based on Figure 1, it is found that the types of errors made by students on indicators presenting relations with arrow diagrams, cartesian diagrams, and consecutive sets of pairs are conceptual errors $(\mathrm{K} 1 \& \mathrm{~K} 2)$.

Look at the answer given by S-3 (see Figure 3), this student already had an idea of the concept of the arrow diagram but had not paired between set $\mathrm{A}$ and set $\mathrm{B}$, after the interview it was known that she already understood the questions, but she did not understand the concept of relations and arrow diagram. This error includes the type of conceptual error (K1). Thus, the conceptual error (K1), in this case, the student already had an image in the presentation of the relationship in various forms but she answered in another form that was not in accordance with the requested question, another form that was close to the arrow diagram. The reason was that she did not understand the arrow diagram and she answered by looking at the context of the sentences in the questions. S-19's understanding was confused with another representation, the Cartesian diagram.

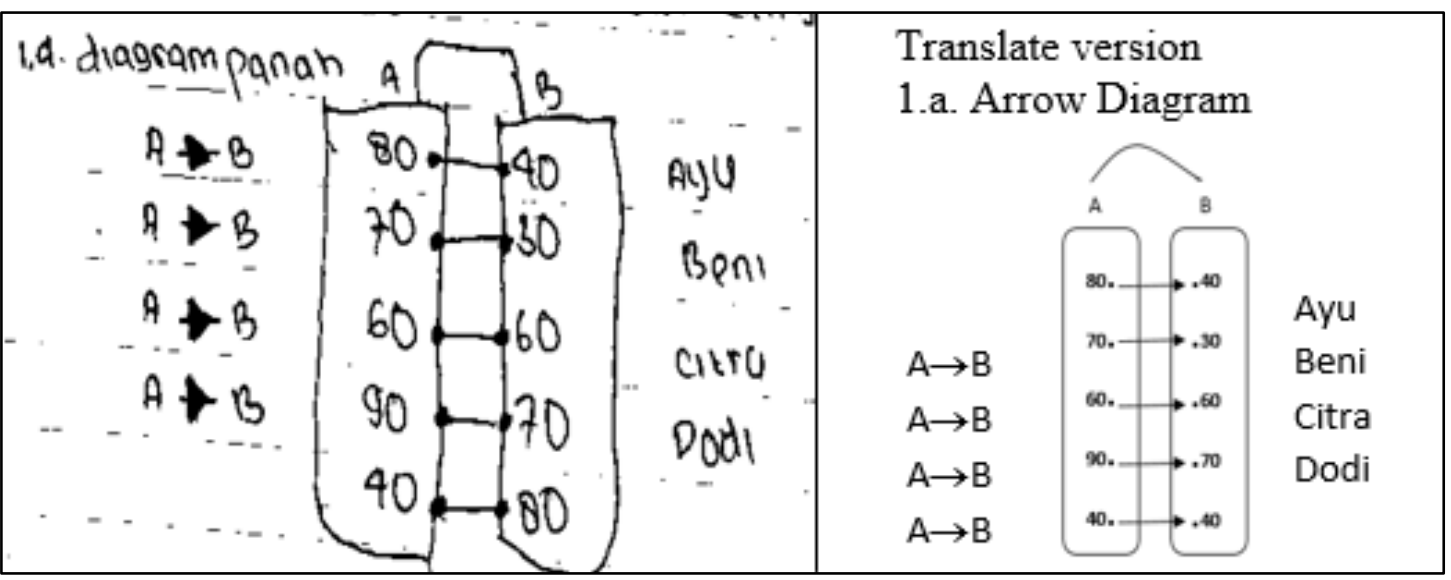

Figure 3. The answer of S-3 on question number 1a

Based on the results of the interview, student's assumptions about arrow diagrams were diagrams with arrows (see Figure 4). Thus, the conceptual error (K2) made by students was that students' understanding was confused with the concept of presenting one relationship with another. Based on the results of the interview, student's assumptions about arrow diagrams were diagrams with arrows on them, so that the students' conception of representations with arrow diagrams, consecutive sets of pairs and Cartesian diagrams was still wrong.

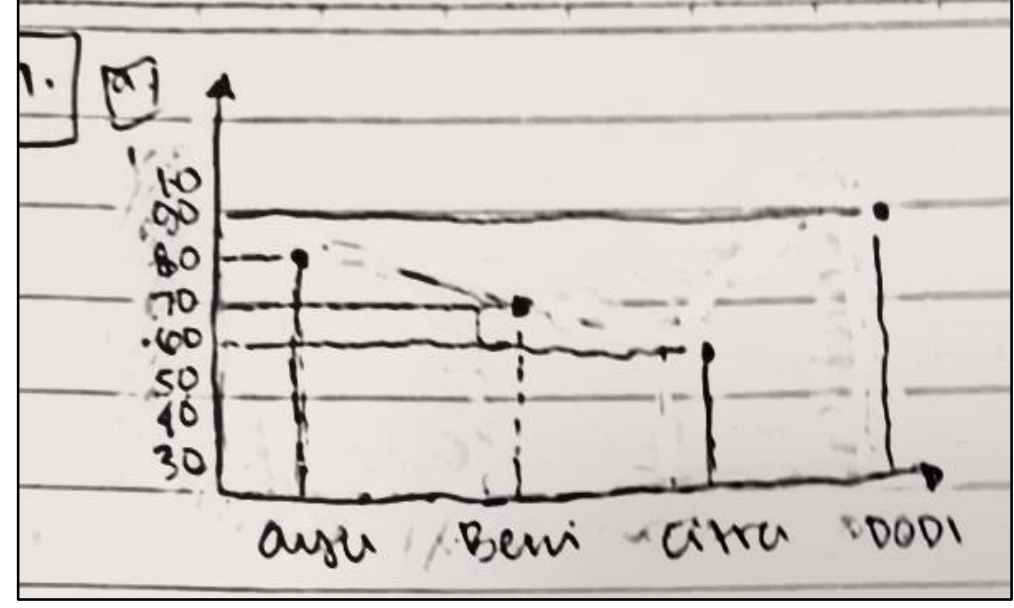

Figure 4. The answer of $S-19$ on question number 1a 


\subsection{Error Analysis on Question Number 2}

The indicator for question number 2 showed examples of functions and not functions. The question can be seen in Figure 5.

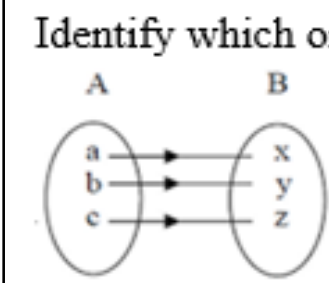

Picture 1

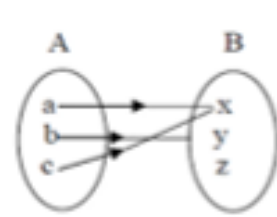

Picture 2

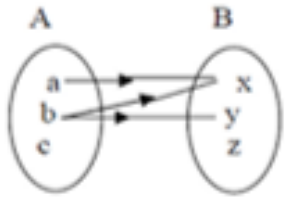

Picture 3

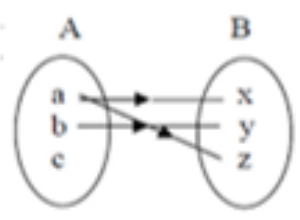

Picture 4

Figure 5. Question number 2 for the second indicator

Based on Figure 1, it was found that the types of errors made by students on indicators showing examples of functions and not functions are conceptual errors (K1 and K2) and technical errors. Error types K1 and K2 will be analyzed.

Figure 6 show that S-3 didn't answer accordingly to the concept of function. So, the conceptual error (K1) made was that the students had understood the problem, identifying a function and not a function but the student answered with another concept. S-3 gave the same answer pattern in picture 1-4. When the interview was conducted, the students already understood the problem, but the students' conception was a function is when there is a parallel straight line.

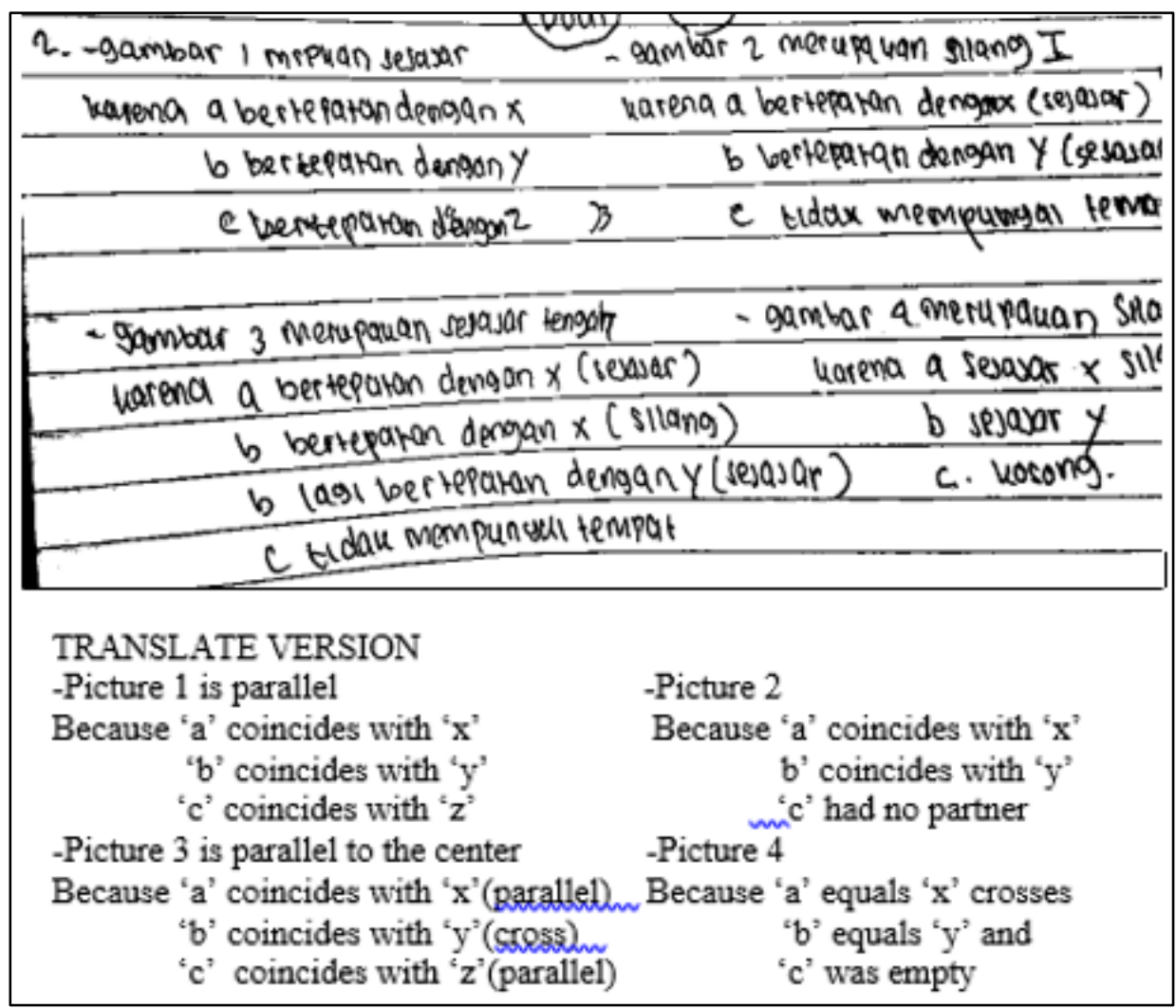

Figure 6. The answer of S-3 on question number 2 
S-22's answer in Figure 7 was correct, but for the reasons given it was still incorrect, because there was an empty domain. Thus, the conceptual error (K2) was incorrect reasons although students had correctly answered. Based on the results of the interview, the students' conception was that it is called a function if the domain and codomain were paired (nothing is empty). It is called not function because there were empty domains and codomains. The domain that the student meant was the one in B area.

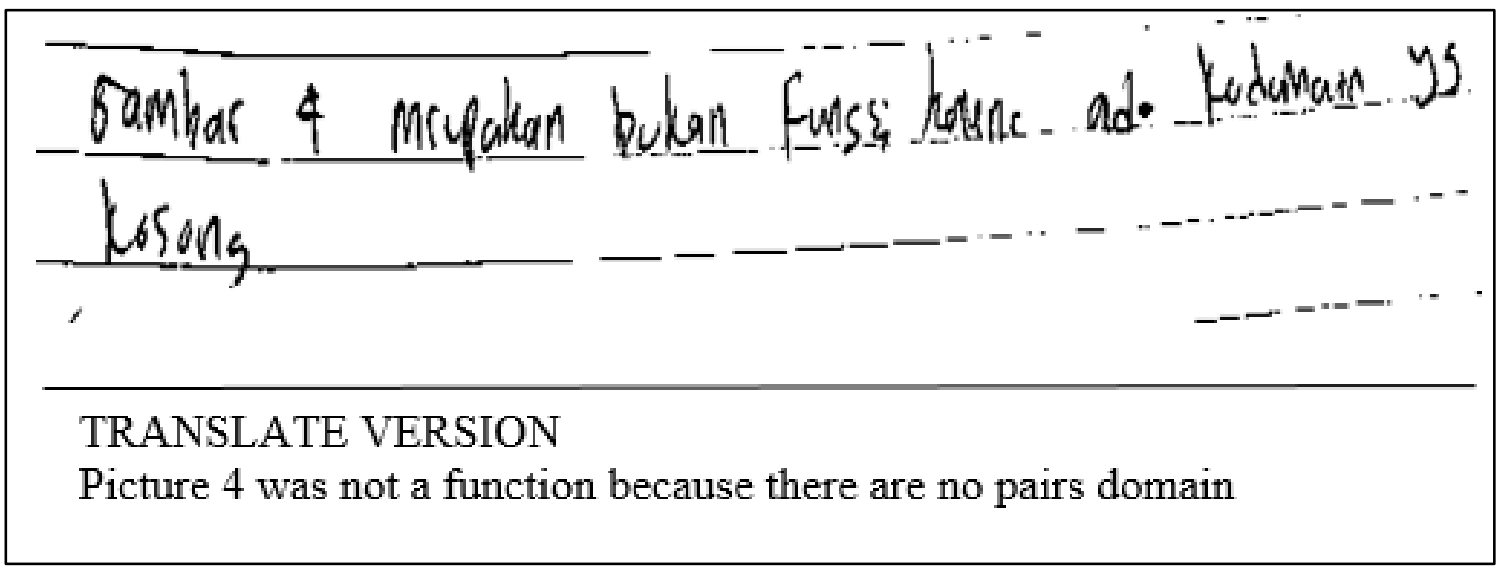

Figure 7. The answer of S-22 on question number 2

\subsection{Error Analysis on Question Number 3}

Indicator of question number 3 is determining the domain, domain and result area of the function. The question can be seen in Figure 8 .

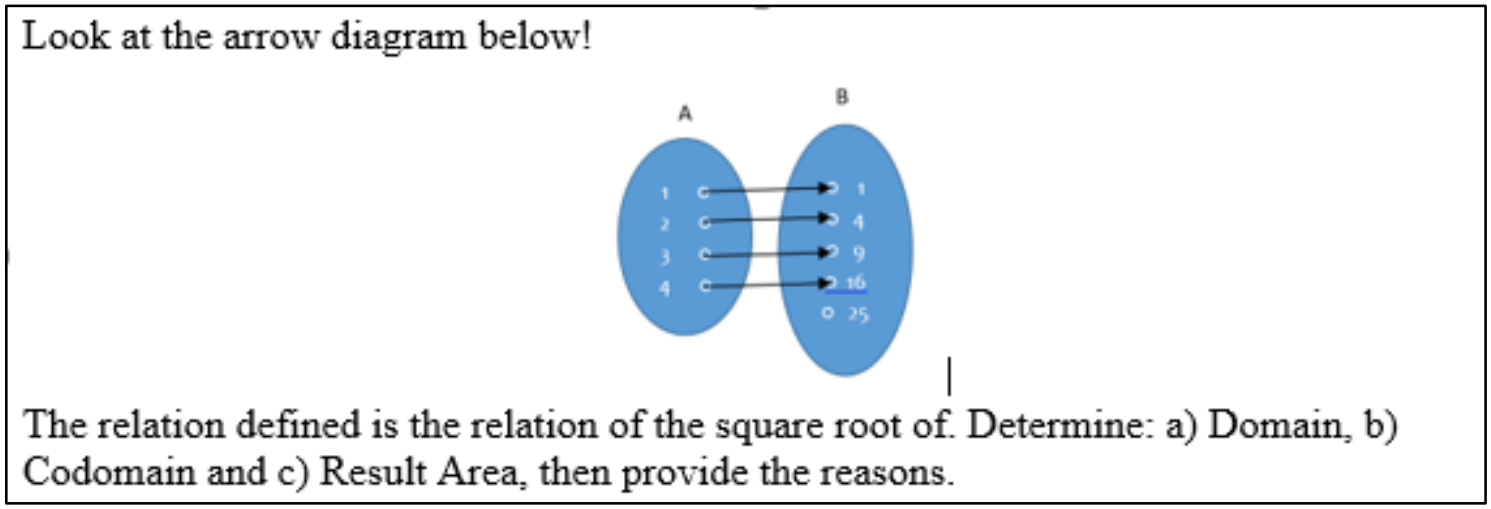

Figure 8. Question number 3 for the third indicator

Based on Figure 1, it is found that the type of error made by students is conceptual error (K1 and K2). Based on Figure 9, the S-2's answer shows that the students already understood the context of the question, but had not shown the conceptual image of the domain, codomain and result area. Based on the results of the interview, the reason was that the students had not yet understood the concept of the domain, codomain and result area. So that the conceptual error (K1) made by students is that the students already understood the problem, determining the domain, codomain and result area, but did not understand the concept of domain, codomain, and result area. 


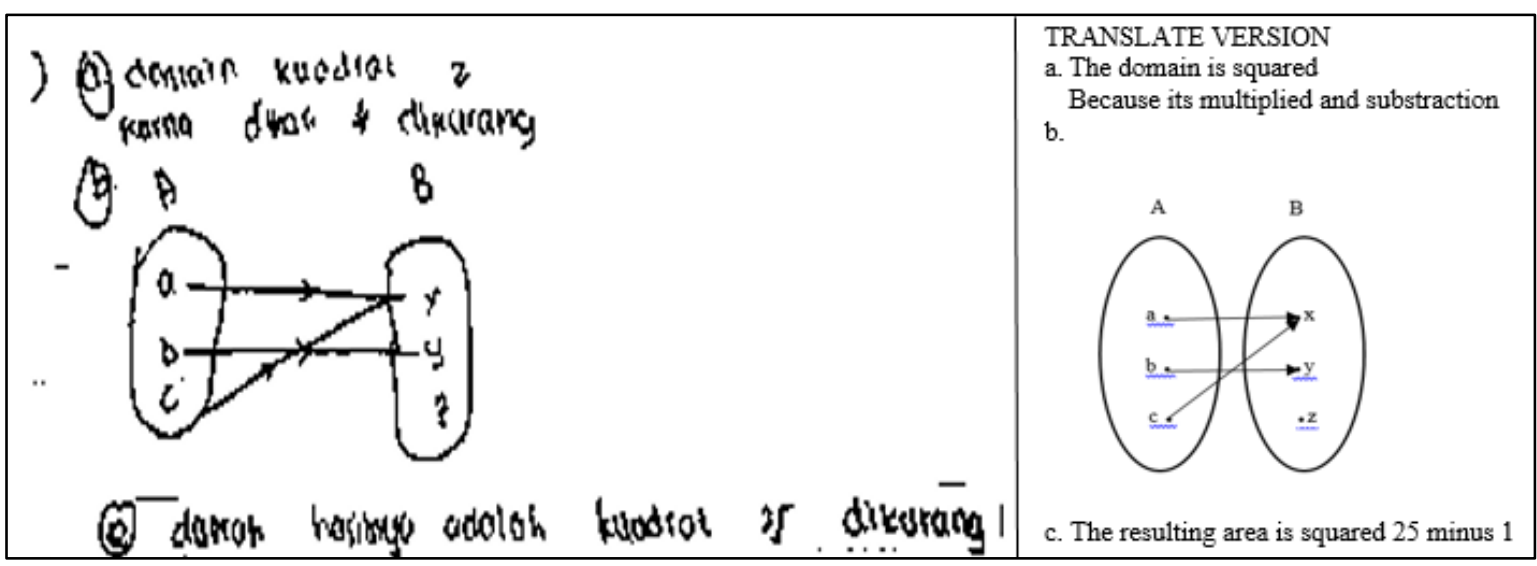

Figure 9. The answer of S-2 on question number 3

The S-14's answer in Figure 10 shows an error in determining the result area. Students already had an idea of the concept that the codomain is the set that will be paired with the domain, but in determining the result area, the students added up all members of the codomain that had pairs, $1+4+9+16=30 . S-23$ assumed that the result area was the final count or the final result so that all the numbers were added up. The conceptual error (K2) made by students was the answers in the results area were still incorrect although they had correct answers in the domain and codomains. Students have a conception that the results area is summing up the elements in the paired domains.

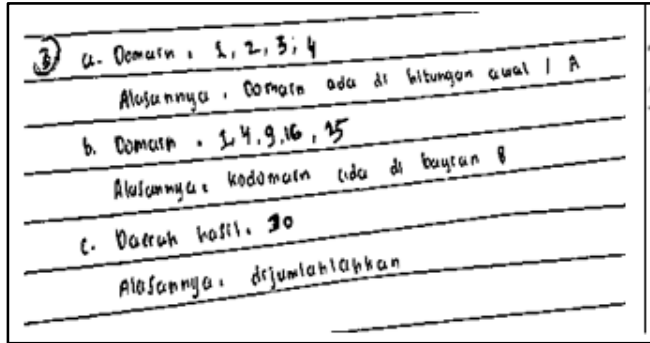

\section{TRANSLATE VERSION}

3. a. Domain $=1,2,3,4$

The reason: Domain in in the initial count / A

b. Domain $=1,4,9,16,25$

The Reason: The Codomain is in part of B

c. The result area $=30$

The Reason: All the values in section of B are added up

Figure 10. The answer of S-14 on question number 3

\subsection{Error Analysis on Question Number 4}

The question indicator of number 4 is solving problems related to relations and functions. The question can be seen in Figure 11.

\section{Andi's Mathematics score every semester has increased by 2 points. Now, Andi's in grade 9 semester I. If Andi's math score in grade 7 semester II is 84, then determine Andi's grade in grade 8 semester II!}

Figure 11. Question number 4 for the fourth indicator

Based on Figure 1, it is found that the types of errors made by students are conceptual errors (K1) and technical errors. Based on Figure 12, S-21 had not answered correctly. The results of the interview stated that the students already understood the context of the questions, but this student did not understand what concepts were used and how to solve the 
questions. So that the conceptual error (K1) made was that he already understood what was known and asked, but did not understand the concepts used.

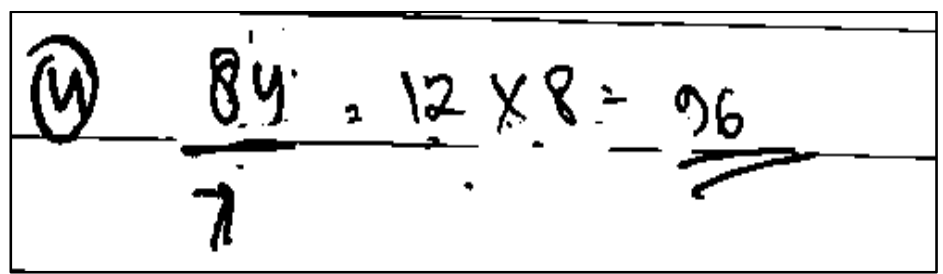

Figure 12. The answer of $S-21$ on question number 4

Meanwhile, the S-26 made technical errors, this student already understood what was known and asked and carried out the calculation procedure, but were not careful in reading the questions (see Figure 13).

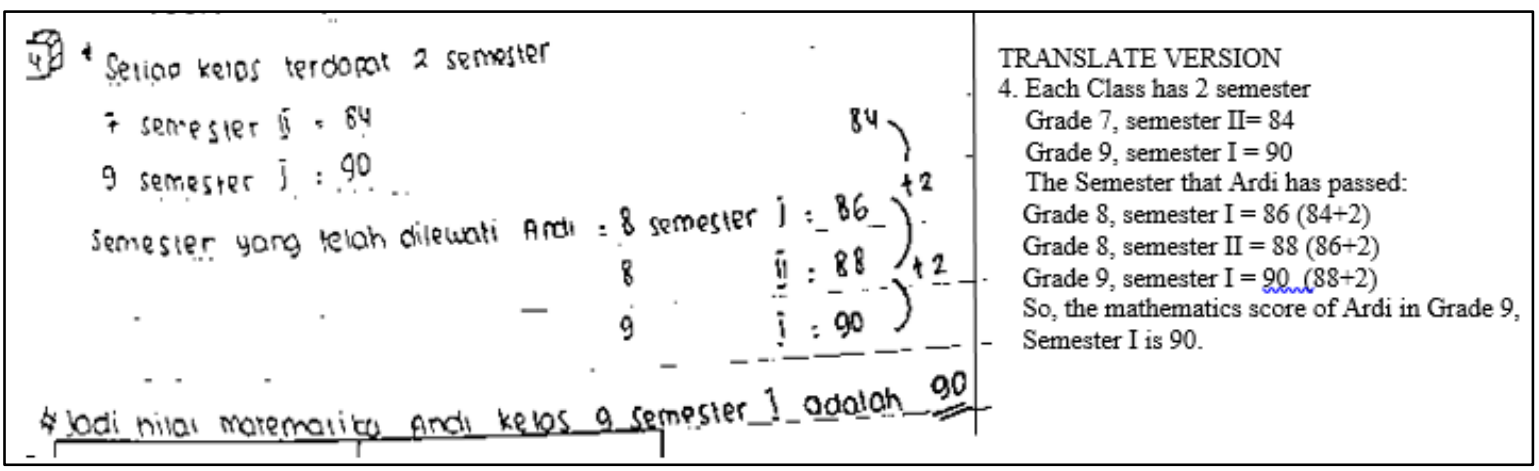

Figure 13. The answer of S-26 on question number 4

\subsection{Error Analysis on Question Number 5}

Indicator of question number 5 is solving problems related to relations and functions in the form of an equation. The question can be seen in Figure 14.

A playground applies an initial rate and an hourly rate, the initial rate is IDR 5,000.00 and the hourly rate is IDR 10,000 !

\begin{tabular}{|c|c|}
\hline Playing duration (hour) & How to calculate costs \\
\hline 1 hour & $5000+(1 \times 10.000)$ \\
\hline 2 hours & $5000+(2 \times 10.000)$ \\
\hline 3 hours & $5000+(3 \times 10.000)$ \\
\hline 4 hours & $5000+(4 \times 10.000)$ \\
\hline$\ldots \ldots$ & $\ldots \ldots \ldots \ldots$ \\
\hline$\ldots \ldots$ & $\ldots \ldots \ldots \ldots \ldots$ \\
\hline a hours & $5000+(\ldots \times 10.000)$ \\
\hline
\end{tabular}

Copy the table on your answer paper, if B (a) is the amount of money it costs to play on the playground for an hour, then write the formula for B (a)!

Figure 14. Question number 5 for the fifth indicator

Based on Figure 1, the type of error made by students is a mistake in understanding the question (M). Errors in understanding the questions made by S-22 was s/he did not 
understand the questions and concepts used, s/he only continued to compute from the table that has been given (see Figure 15).

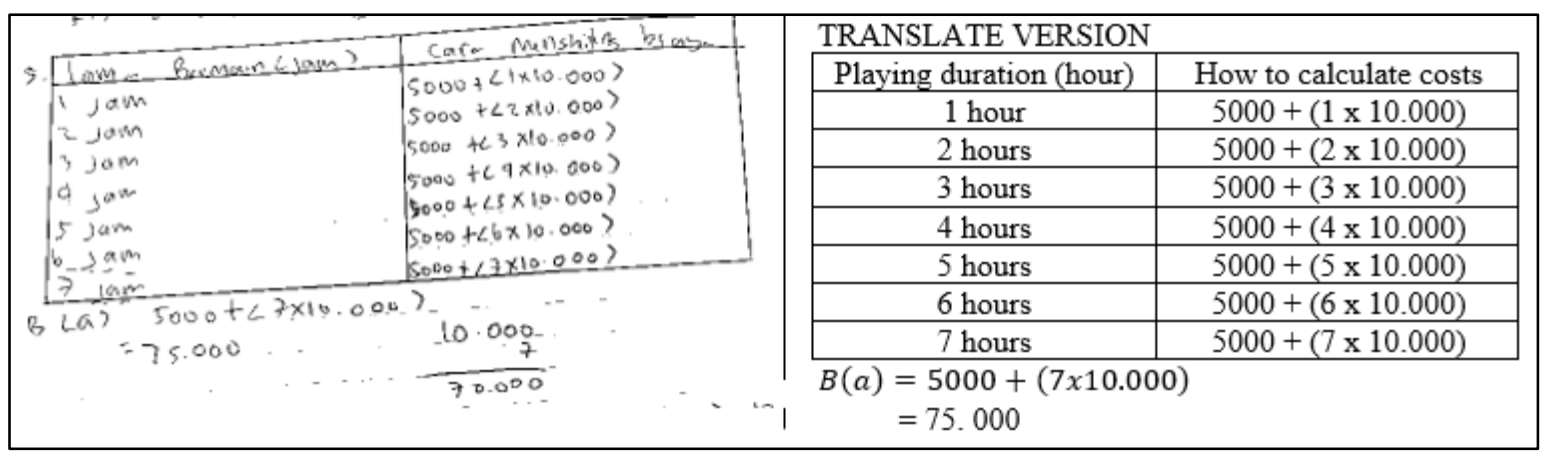

Figure 15. The answer of S-22 on question number 5

\subsection{Error Analysis on Question Number 6}

The indicator of question number 6 is to express the function in the equation formula and the graph of the function. The question can be seen in Figure 16.

Given a function $f(x)=3 x-4$, where domain $\mathrm{A}=\{6,8,10,12\}$ and codomain of the natural numbers. a) Find $f(6), f(8), f(10)$ and $f(12) !$, b) Suppose that the answer in point a is a set B. What is set B called? c) Express the function with a graph.

Figure 16. Question number 6 for the sixth indicator

Based on Figure 1, it is found that the types of errors made by students are conceptual errors (K1 and $\mathrm{K} 2$ ) and procedural errors (P). Figure 17 show that S-14 already has a conceptual image of finding the value of the function by substituting the $\mathrm{x}$ value into the function, but the $x$ variable remains in the final result and multiplying the value of the known variable by the second term. Based on the interview, this student forgot to determine the procedure for determining the value of the function, as she remembered that the value in the brackets was multiplied, but the she forgot to multiply it by one (syllable) or both. So that at point a, the student made procedural errors, the students already understood the questions and concepts used but were wrong in carrying out the calculation procedure. In point $b$, the student made a conceptual error (K1), that is, the students already understood the questions but she was not correct enough to relate to the correct concept. In point c, students made conceptual errors (K2). In this case, students already understood the questions and concepts that must be used but had wrong understanding of the concept of the domain and result area. 


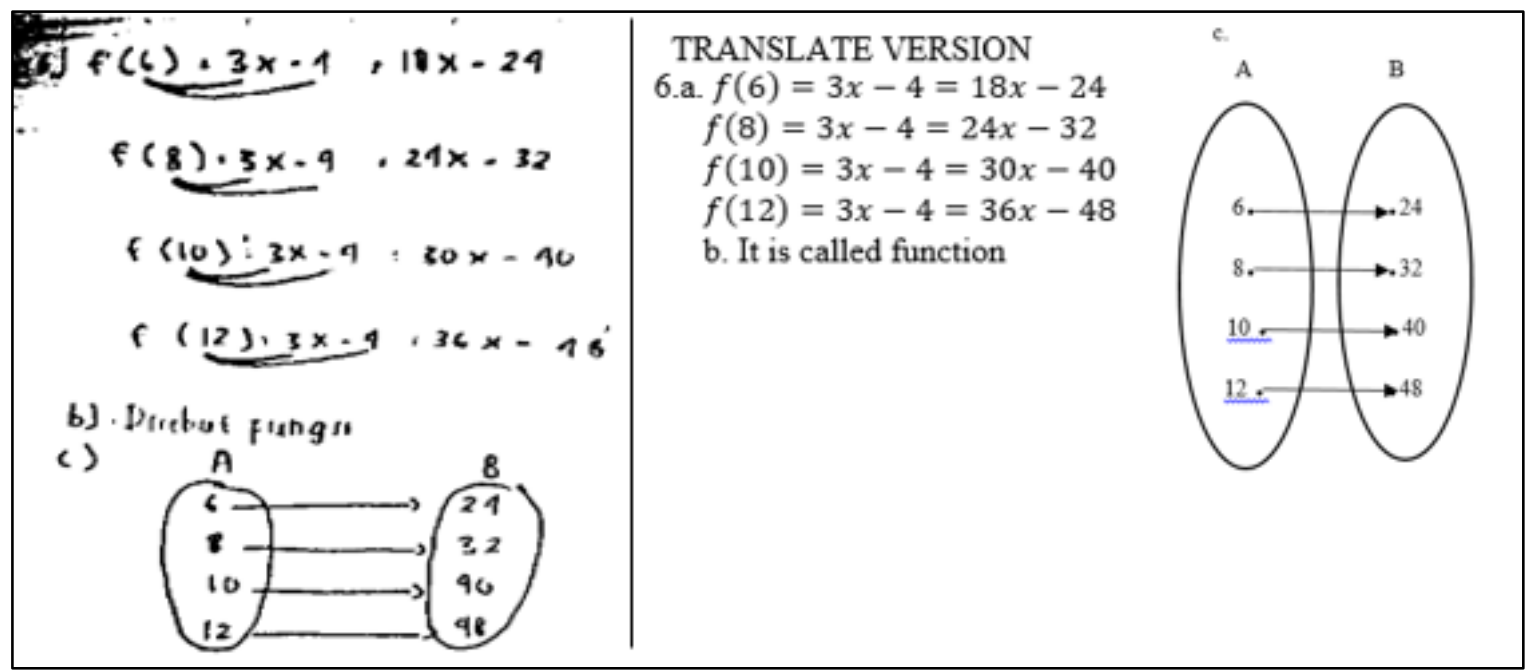

Figure 17. The answer of S-14 on question number 6

The students S-25 can perform operations to determine the value of the function, but in point $b$ students still cannot distinguish between codomains and result areas, and in point $\mathrm{c}$ in drawing function graphs there are still errors in writing the correct domain on the $\mathrm{x}$-axis and the result area should be on the y-axis (see Figure 18). Based on the results of the interview, this student called the domain as the group that was on the right and the codomain as the group was on the left, the result area is the final result. As for the graph, s/he assumed that there were no certain conditions to place the domain and the result area.

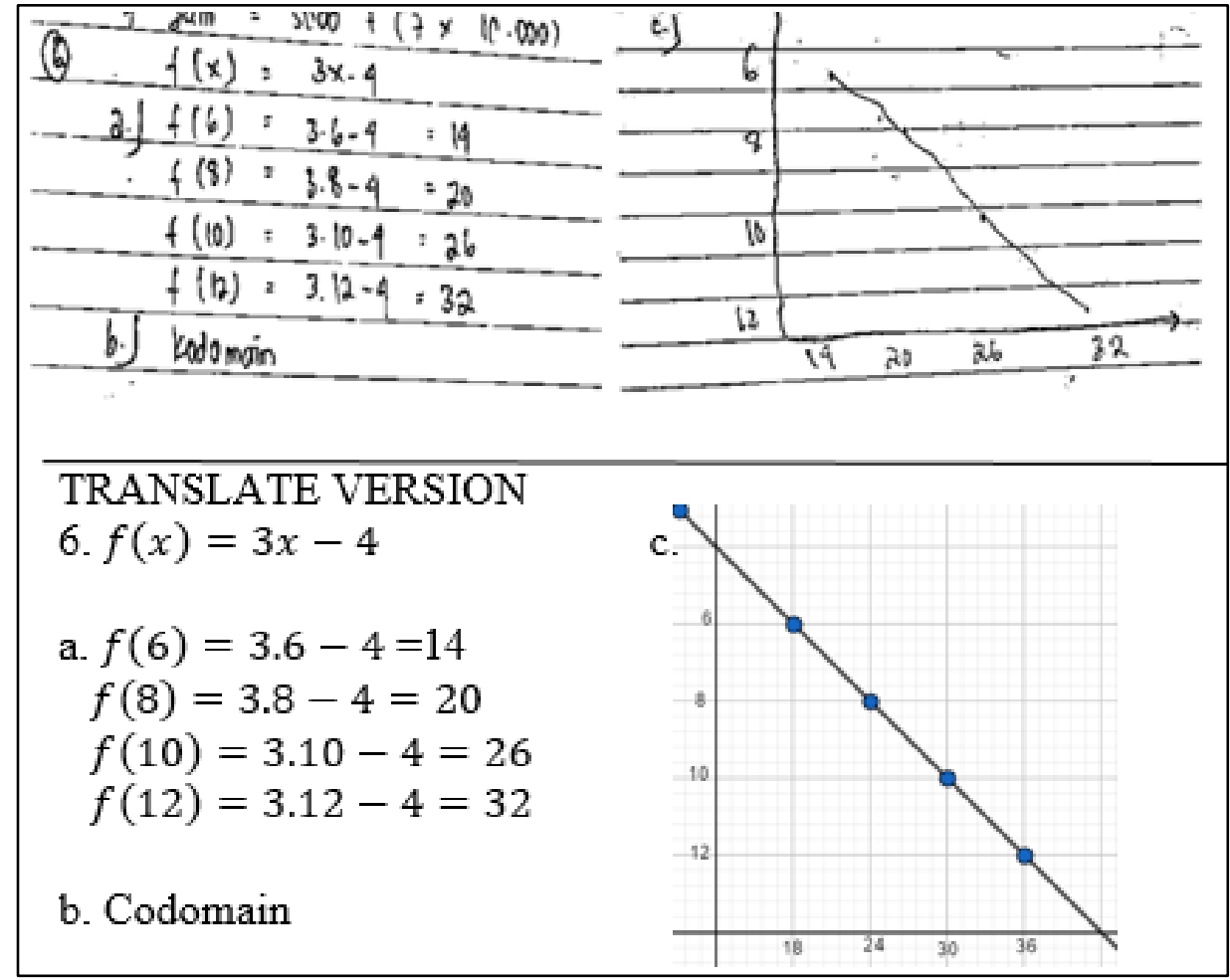

Figure 18. The answer of S-25 on question number 6

Based on the results of the answer analysis, students who made conceptual errors (K1), students had understood the questions well, but in answering it was not in accordance 
with the concept used. The following is the conceptual error type one (K1) on each question indicator: (a) In presenting the relationship with an arrow diagram, students presented it in another form that was close to the arrow diagram; (b) In identifying functions and not functions, students saw from the picture presented in the question, there were several parallel and crossed lines, so that students made mistakes in understanding the concept of function seen from parallel or cross arrows; (c) Students did not understand the concept of domain, codomain and result area; and (d) In solving problems related to the concept of relations and functions, students did not understand what concepts used in solving problems.

The following is the conceptual error type two (K2), students already understood the questions well and even they answered the questions correctly but they gave wrong reasons and were associated with concepts other than relations and functions: (a) In presenting relations with arrow diagrams, students' understanding was confused on the concept of presenting the form of relations and functions, one with another. The reason was that students had a different conception of the arrow diagram; (b) In identifying a function and not a function, students had a conception that it was called a function if the domain and codomain were paired (there was no one that was not paired). It was called not a function because there were domains and codomains that did not have a partner; (c) Students had correctly answered for the domain and codomain, but the answer in the result area, the students had a conception for the result area that summing up the elements in the paired codomain; and (d) In solving problems related to the concept of relations and functions, they had used the requested concept, but in graphical presentation students did not pay attention to the location of the domain and result area.

Types of conceptual errors (K1) and (K2) are closely related to students' knowledge of the concept of relations, functions, domains, codomains, result areas and their presentation using arrow diagrams, sequential pairs and Cartesian diagrams. For students who made conceptual errors (K1), they had a conceptual image that was asked for in the questions, but did not have the proper knowledge of the concepts, so they answered by paying attention to sentences in questions and other concepts outside the concept of relations and functions. This showed that the understanding of other concepts that were already owned by students affected students' understanding of concepts in the next material. These concepts were understood by students through visible characteristics. This is in accordance with (Slavit, 1997), that a person understands the concept through various examples of functions and seeing its properties, students can understand the function as an object that has these properties.

For students who made type two conceptual errors (K2), the reason was that they had a different conception of the correct concept. The wrong conception of students was the cause of mistakes made by students in relation to material and functions. The results of research by Hatısaru and Erbaş (2010) indicate that vocational secondary students have very weak perceptions of the concept of function. Kamariah and Marlissa (2016) also give similar results that students with the average ability had misconceptions, determining relations which are functions and determining certain values that fulfill a function.

Other error made by students was procedural errors, which are related to finding the value of the function of an equation. Students had not been able to solve problems systematically which involved a thinking process. The cause of this error was students forgot how to perform the procedure for substituting variable values into equation functions. Research results by Hakim et al. (2020) show that the percentage of procedural errors committed by grade eight students at a junior high school in Yogyakarta in the 2019/2020 school year in solving relationship and function problems is 93.7.\%. In addition, the technical errors made were in the indicators of solving relationship and function problems. Students were not careful in reading what questions were asked, even though the concepts 
and procedures were correct but the expected answers were still wrong. The students already had the concept description but there was inaccuracy from the students, resulting in errors. Errors in understanding questions also occurred in indicators of solving problems of relations and functions, students did not understand what was known and asked about the questions and the use of concepts. Students did not understand what was being asked so they did not have a conceptual description that will be used in solving the questions. The three types of errors were closely related to cognitive factors and students' conceptual images. This explanation is in line with Tall and Vinner (1981) that concept images consist of all cognitive structures in an individual's mind that are different from the formal concept definition and contain several factors that cause cognitive conflict. Tall (1988) states that empirical research has emphasized that a person constructs a mental image of a concept in a way that may be inconsistent, and previous student experiences can influence the meaning of the phenomenon when students meet in a new context.

\section{CONCLUSION}

Based on the results of the study, $62 \%$ of students did the first type conceptual and $21 \%$ of the students did the second type conceptual error. For students who make type one conceptual errors (K1), they have a conceptual image that is asked for in the question, but do not understand the correct concept, so that students solve the problem by paying attention to the sentence on the question and answer with other concepts that have nothing to do with the concept of relations and functions. For students who make type two conceptual errors (K2), students have a different conception of the correct concept. In procedural errors, students have not been able to solve problems systematically which involve a thinking process. In the misunderstanding of the questions, students do not know what is being asked so they do not have a conceptual description that will be used in solving the questions. Then in technical errors, the concept description is already owned by students but there is inaccuracy from students, resulting in errors.

Incorrect students' conception regarding Relation and Function material are: (a) The arrow diagram is shown by a Cartesian diagram and arrows are given on both axes; (b) It is called a function if the domain and codomain are paired (none of which is empty), it is called not function because there are empty domains and codomains; (c) The result area is summing up the elements in the paired codomain; (d) Domain is the group that is on the right and the codomain is the group that is on the left, the result area is the final result; and (e) There are no rules for placing domains and codomain in drawing graphs of functions.

\section{REFERENCES}

As'ari, A. R., Tohir, M., Valentino, E., Imron, Z., \& Taufiq, I. (2017). Buku guru matematika (Revisi). Jakarta: Pusat Kurikulum dan Perbukuan, Balitbang, Kemendikbud.

Bell, B. F. (1993). Children's science, constructivism and learning in science. Victoria: Deakin University Pers.

Bell, F. H. (1981). Teaching and learning mathematics (in secondary school). IOWA: WnC Brown Comp.

Blanco, L. J., Lizarazo, J. A. C., Figueiredo, C. A., \& Contreras, L. C. (2014). The concept of function and his teaching and learning. Far East Journal of Mathematical Education, 12(1), 47-78. 
Hakim, H., Solechatun, S., \& Istiqomah, I. (2020). Analisis kesalahan siswa dalam menyelesaikan soal uraian matematika kelas VIII SMP Taman Dewasa Ibu Pawiyatan. UNION: Jurnal Ilmiah Pendidikan Matematika,8(1), 63-72. https://doi.org/10.30738/union.v8i1.7611

Hatısaru, V., \& Erbaş, A. K. (2010). Students' perceptions of the concept of function: The case of Turkish students attending vocational high school on industry. ProcediaSocial and Behavioral Sciences, 2(2), 3921-3925. https://doi.org/10.1016/j.sbspro.2010.03.617

Hidayat, W., \& Sariningsih, R. (2018). Kemampuan pemecahan masalah matematis dan adversity quotient siswa SMP melalui pembelajaran open ended. JNPM (Jurnal Nasional Pendidikan Matematika), 2(1), 109-118.

Irawati, R., Indiati, I., \& Shodiqin, A. (2014). Miskonsepsi peserta didik dalam menyelesaikan soal pada materi relasi dan fungsi kelas VIII semester gasal SMP Negeri 4 Kudus. MATHEMATICS AND SCIENCES FORUM 2014.

Istiqomah, D. N. (2015). Learning obstacles terkait kemampuan problem solving pada konsep fungsi matematika SMP. In Prosiding seminar nasional matematika dan pendidikan matematika UNY, 407-412.

Johari, P. M. A. R. P., \& Shahrill, M. (2020). The common errors in the learning of the simultaneous equations. Infinity Journal, 9(2), 263-274. https://doi.org/10.22460/infinity.v9i2.p263-274

Kamariah, K., \& Marlissa, I. (2016). Analisis kesalahan menyelesaikan soal relasi dan fungsi pada siswa kelas VIII SMP Negeri Buti Merauke. Magistra: Jurnal Keguruan dan Ilmu Pendidikan, 3(1), 30-42.

Kariadinata, R., Yaniawati, R. P., Sugilar, H., \& Riyandani, D. (2019). Learning motivation and mathematical understanding of students of islamic junior high school through active knowledge sharing strategy. Infinity Journal, 8(1), 31-42. https://doi.org/10.22460/infinity.v8i1.p31-42

Kiat, S. E. (2005). Analysis of students' difficulties in solving integration problems. The Mathematics Educator, 9(1), 39-59.

Ministry of Education and Culture of the Republic Indonesia [MECRI]. (2016a). Peraturan menteri pendidikan dan kebudayaan republik Indonesia nomor 21 tahun 2016 tentang standar isi pendidikan dasar dan menengah. Jakarta: Kementerian Pendidikan dan Kebudayaan Republik Indonesia.

Ministry of Education and Culture of the Republic Indonesia [MECRI]. (2016b). Peraturan menteri pendidikan dan kebudayaan republik Indonesia nomor 24 tahun 2016 tentang kompetensi inti dan kompetensi dasar pelajaran pada kurikulum 2013 pada pendidikan dasar dan pendidikan menengah. Jakarta: Kementerian Pendidikan dan Kebudayaan Republik Indonesia.

Sfard, A. (1991). On the dual nature of mathematical conceptions: Reflections on processes and objects as different sides of the same coin. Educational studies in mathematics, 22(1), 1-36. https://doi.org/10.1007/BF00302715

Simon, M. A. (2017). Explicating mathematical concept and mathematical conception as theoretical constructs for mathematics education research. Educational Studies in Mathematics, 94(2), 117-137. https://doi.org/10.1007/s10649-016-9728-1 
Slavit, D. (1997). An alternate route to the reification of function. Educational Studies in Mathematics, 33(3), 259-281. https://doi.org/10.1023/A:1002937032215

Tall, D. (1988). Concept image and concept definition. Senior Secondary Mathematics Education, 1983, 37-41.

Tall, D., \& Vinner, S. (1981). Concept image and concept definition in mathematics with particular reference to limits and continuity. Educational studies in mathematics, 12(2), 151-169. https://doi.org/10.1007/BF00305619

Viholainen, A. (2008). Incoherence of a concept image and erroneous conclusions in the case of differentiability. The Mathematics Enthusiast, 5(2), 231-248.

Zetterberg, H. L. (1966). On theory and verification in sociology. Science and Society, 30(1), 114-117. 